\title{
HOW TO MAKE SCANSION EARN ITS KEEP IN SCHOOLS 1
}

\author{
B.E. Lewis, University of Port Elizabeth
}

Some years ago, when asked for comr..ents on the new core syllabus for Senior Certificate Latin, I suggested that scansion be eliminated. My reasons were twofold: for one thing I felt that the mark allocation simply did not justify the amount of time needed to master the skill. (One is acutely conscious of "cost-effectiveness" these days.) Secondly, in 25 years of lecturing I have never found a first-year student - and I must include myself - who proved, by the ability to read Latin verse as verse, that scansion was anything more than an artificial exercise devised for its own sake. (The utilitarian argument again.) I am not now justifying the retention of a difficult hurdle for pupils to surmount, invoking the witty adage that invention is the mother of necessity. There is a practical reason to recommend scansion: clearly the sound of language was of major importance to the Romans, as readers used to read aloud to themselves, and the recitatio was a common event in the life of litterateurs especially under the early Empire. Since the current format of examination papers shows how far pupils' literary critical originality and frank opinion are encouraged, I now hope to give some practical help to teachers to prepare their charges a puero for an enjoyable and rewarding encounter with scansion.

The key to success is, I believe, to cultivate merely by example (and thus unbeknown to the pupils) an awareness $a b$ init. of firstly vowel quantities and secondly word stress. If the spadework is done early, pupils will absorb the required knowledge piecemeal, and will be saved the learning of a mass of new and perhaps confusing material when scansion is taught formally $2 \mathrm{~A}$ further aim is to give pupils the tools that may lead them to the exciting discovery for themselves of how the Latin poets made metre suggest meaning. As a didactic principle I have found that references to languages within the experience of the pupil eradicate the typical schoolboy notion that Latin is a language confined to dull and musty text-books.

\section{AXIOMS TRUE AND FALSE}

To this end some outmoded theories will need to be swept away. The first mistaken assumption is that we know for certain how Latin verse was read.3 It is not necessary to concern ourselves here with academic controversy. 4 The second misconception which dates

I A shorter form of this paper was read at a symposium for teachers of Latin in the Eastern Cape at Rhodes University, Grahamstown on 10 August 1990.

2 The vocabulary-book prescribed by the Department of Education and Culture, viz. Smuts, Bruwer \& Van Stekelenburg, Lexis Latina. Pretoria: Academica Press, 1985, marks stress and quantity.

Dr. J.M. Claassen has written an article on scansion which teachers will find most profitable to consult. I differ with her on one point, viz. the terminology of vowels "long by position". See "The Scansion of Latin Verse", Akroterion 33, 2\&3, June/Sept. 1988, 79-84.

3 "The whole question of stress or 'ictus' has been much disputed by modern scholars." Raven, D.S. (1965:153).

4 Allen, W.S. (1973) has pointed out the problem areas. 
back to one of the ancient grammarians, 5 and the perpetuation of his error, is the designation of certain vowels in poetry as "long by position". An overlooked fact is that Latin had a stress accent.

It was a shock to my ears as a first-year student to hear my lecturers pronouncing the names Hánnibal and Cicero, but Hannibalis and Cicerbnis. We do know for certain that this is how a Roman world have stressed the names. The rules, which apply to words of two or more syllables, are simple: if the second-last vowel is long, the stress falls on that syllable; if the second-last vowel is short, the accent falls on the third-last syllable. It need come as no surprise to pupils to hear these variations if they are made aware of the similar shifts of stress and change in vowel sounds in English, e.g. presént, presentátion; compáre, cómparable; active, activity. The teacher may inculcate the habit of correct pronunciation merely by practical application of the rules.

\section{RECITING PARADIGMS AND READING TEXTS IN CLASS}

It seems that the habit of giving greater volume to the termination when learning paradigms by heart, in order to emphasise the differences between cases and persons, and then carrying over this artificial stress to the words in their prose context, is one factor responsible for obscuring the authentic stress of Latin. Scholtemeijer and Hasse (1989) are to be commended for observing at elementary level the change in the placement of accentuation.

The inconsistency in the traditional pronunciation of vowel sounds gives a misleading impression of how the Romans spoke. One hears amo with the $o$ as in coat, but agrorum with the $o$ as in caught; capieris with the $e$ as in South African English fare, but capietur with the $e$ as in fate. Great effort is required of the teacher to standardise the pronunciation of long vowels, which did not vary as we tend to make them behave.6 I am not in favour of pedantic and exaggerated pronunciation of any kind, and especially not of the stilted so-called "new pronunciation".7 One recalls the amusing short story of A.P. Herbert about a lawyer making his first appearance in court and bamboozling the judge with his exotic-sounding utterances (but strictly according to the New Pronunciation) like ooltrah weerayze, day yooray, and pahree pahsoo. In my opinion pupils need to be trained to listen to the difference between short and long vowels (those called "long by nature" in the time-honoured parlance) when they are first taught their vocabulary and paradigms. May I plead for the eradication of a few common mispronunciations? Volo and bonus are seldom rendered correctly with a short first $o$, though invariably velle and bene are rightly given a short first $e$. The variation of the vowel in these two words, both from the same root, is directly comparable with the alternation of vowels in English got and get; the rule also affects foot and feet, and Afrikaans kies/gekose and

$5 \quad$ "Thus in Dionysius Thrax (17U) a long syllable is one which contains a long vowel or a diphthong or which contains a vowel followed by two consonants; and a short syllable is one which contains a short vowel not followed by two consonants. The ambiguous terminology, however, inevitably leads later writers into confusion. "(1973:53-4).

6 Allen has a useful appendix on pronunciation in Vox Latina (1965:111-112). However, analogy with the sounds of Afrikaans is more meaningful than with French or German in South African schools.

7 Officially the New Pronunciation has been current in Afriaans-medium schools for nearly a century, but (to judge from my Afrikaans-speaking students) variations do occur. 
soek/gesogde. There is infallible proof that the $a$ vowels of facio and cado are short, though they are often given a long initial vowel.

I give some examples of the noteworthy quantities of vowels in nouns:

1. The abl. sing. vowel is long, except for the $-e$ of the third declension where there is no vowel forming the "theme". (Kennedy (1962 para. 35a:18) correctly classifies the second declension the $o$-stem declension, and in fact the -0 of the dat./abl. sing. and acc. and gen. pl. prove this.)

2. In the masc. and fem., the acc. sing. always has a short vowel before the $-m$ and the acc. pl. always a long vowel before the $-s$.

3. The nom. pl. always has a long vowel or diphthong except for neuters.

4. All neuters have short vowels in the nom./acc. sing. and pl.

A handful of verbal forms could be given their due quantities when the paradigms are learnt. I would suggest the following:

1. the long $-o$ of the 1st pers. sing. act.

2. the long $-i$ of the 1 st pers. sing. perf. indic. act.

3. the long vowel before the -re of the pres. inf. act., with the exception of the 3rd conjugation.

4. the long vowel before the personal endings of the 2nd pers. sing. and pl. and 1st pers. pl. act. and pass.

e.g. amäris, amēmur, regāmini, iss and $\overline{v i s}$.

There are several exceptions, mainly in irregular verbs - just where one would expect to find them, viz.

(a) ěs, sŭmus, ̌̌stis; ferimus

(b) pres. indic. act. of the 3rd conjugation, e.g. regis, regimus and, less obviously,

(c) in the $b$-futures, e.g. -b̆s, -b̆mur and fut. perf. act., e.g. fuerĭs, audiverittis, as opposed to the perf. subj., fueris and audiveritis.

\section{OLD RULES THAT DON'T WORK}

Latin did distinguish between long and short vowels, e.g. in

mālum = apple, and mălus = bad; pŏpulus = people, and pōpulus = poplar tree; regĕris (pres.) and regeris (fut.). Thus vowel quantity is a determinant of meaning and cannot be changed at will.

We have all been amused at the riddle, mater mea sus mala est, which we are assured is not an insult to our parentage. 8 Applying the old system, we would be compelled by logic to say that quantities varied between prose and verse; by the rule of "long by position" therefore, distinctions such as those mentioned in the word-pairs above could be obliterated in poetry and

8 Read: mater, (voc.) meā (imperative of meo), sus măla (acc. of mălum = apple) èst (3rd sing. of edo). 
could cause confusion. In reading Latin poetry we never hear et pronounced as if it were "ate", when the next word begins with a consonant; logically factum should have a long $a$ and velle should have a long first $e$; fortunately our ears are spared such barbarisms. (Greek offers cogent proof of the absurdity of the rule of "long by position".9)

\section{NEW RULES FOR OLD}

Professor Allen's illuminating explanation'0 has cleared up the confusion between vowel quantity and syllable quality. What the Sanskrit grammarians observed of their own language he applied to Latin. There are a few basic rules: (1) Only vowels have the property of quantity, i.e. are either long or short. (2) Only syllables have the property of quality, i.e. are either heavy or light. (3) A long vowel automatically makes the syllable in which it occurs, heavy.

If a short vowel stands in front of two consonants, the syllable is heavy, e.g. amnis, mēnsis, missum. However if a short vowel stands in front of one of the following groups of two consonants: $p t c b d g$ (the mute consonants) as well as $f$, plus an $l$ or $r$ (the liquid consonants) the syllable in which the short vowel occurs, may be either heavy or light, depending on the dictates of the metre and/or the intention of the poet, e.g. pătrem, ăgrarius. It is heartening to see that at last the new terminology is gaining wider acceptance.11 But we shall no doubt have to live with the misrepresentation of vowels being long by position for as long as teachers do not introduce Allen's sensible rules.

\section{APPLYING THE NEW CONCEPTS TO SCANSION LESSONS}

As a means of avoiding confusion, which arises from the use of one set of symbols to denote two separate categories, viz. vowel length and syllable quality, I propose the use of different signs (such as $/ \mathbf{0} /$ and $/ \mathbf{x} /$ ) to denote short and long vowels respectively. This notation may be used when indicating the quantities of vowels in the lower standards, provided that pupils observe carefully what they hear, and enquire what vowels are pronounced long and what short; the traditional symbols / / and / / may be kept for indicating heavy and light syllables. Little needs to be done when teaching scansion other than to (1) revise quantities already learnt with vocabulary and paradigms; and (2) state the three rules that Allen propounded, and perhaps add a fourth, which need only be recognised in practice, viz. where the word is a compound containing two consonants in the middle, and the first consonant belongs to the prefix, the syllable is heavy, e.g. $\bar{a} b$-rumpo and $s \bar{u} b$-labor, even though the $a$ and $u$ are short vowels. Pupils may be told that only in the latter half of the hexameter did the poet strive to make the accent of the word coincide with the metrical beat (which fell on the first syllable of the foot). The following verses from Aeneid IV, 1-4 show the positions of word stress $(\Omega$ and

$9 \quad$ It has separate symbols for its long and short $e$ and long and short $o$. If a short $o$ or $e$ became long by position, one would expect to find the spelling in poetry changed. I know of no manuscript which shows this type of aiteration.

10 "It will be convenient first to consider the Indian doctrines ... The two grades are referred to as 'heavy' ... and 'light' ... It will be noted that Sanskrit here makes a clear terminological distinction between the degrees of quantity and those of vowel length." (1973:153).

11 E.g. in the metrical appendix to The Cambridge history of classical literature II, 936-937. 
metrical stress (1); where they coincide this is indicated by an $\mathrm{X}$ :

\author{
ât re/gìna grá/vì | iam/dữdum/ saứcia/ cứra \\ vừnus á/lìt vé/nìs |'éét/caếco/ cầrpitur/ lygni \\ mừlta ví/rì vír/tùs | áni/mò mul/tưsque re/cứrsat \\ gềntis hó/nòs; haé/rènt | in/fixixi/pếctore/ vulltus
}

There were in fact three forces operating simultaneously, viz. word stress, metrical beat, and the different qualities of syllables.

\title{
READING POETRY AND LISTENING TO THE EFFECT OF SCANSION
}

The object of this paper is to show how scansion can help the pupil to discern the atmosphere of a passage from the use and combination of heavy and light syllables. A few examples from Vergil will suffice. The interpretation I offer is subjective, and may well be contradicted by the personal response of others.

An interesting variation of tempo and mood is achieved by the scheme of scansion in the scene in Book IV of the Aeneid after Dido has inflicted the fatal wound.
664 cōnlāp/s(am) āsp̌č̆/unnt | cŏmŭ/tēs, èn/sēmquĕ crŭ/ōrĕ
665 spūmān/tēm spār/sāsquĕ $\mid$ mă/nūs, ìt/ clāmŏr ăd/āltă
666 ātrĭă,/ cōncūs/sâm | bāc/chātūir/ fāmă pĕr/ ūrbēm
667 lāmēn/tīs gĕmĭ/tūqu(e) | èt/ fēmǐně/o ŭlư/lātū
668 tēctă frě/mūnt, rěsŏ/nāt | māg/nīs plāng/ōrĭbŭs/āēthēr

In 664 and 665 the heavy syllables in cōnlāps(am) and spūmāntēm spārsās suit the languor of the dying woman and the paralysis caused by the wound, but the light syllables in ensemque crŭorĕ 12 imitate the rapid spurting of blood. By the use of a large number of heavy syllables, Vergil skilfully creates a contradiction in his auditory images between the sound travelling to all parts of the palace, and Rumour rushing madly about the city. We would suppose him to reflect the speed of sound through the use of more light syllables; but the heavy syllables suggest the heaviness of heart, especially in the action words, it and bacchatur, 13 and attribute to the news an unwillingness to spread. In verse 666 foot- and word-end coincide twice which is unusual in Vergil. These so-called diaereses add to the staccato effect. In 667 the expected elision does not take place between femineo and ululatu. The jerkiness caused by the hiatus, and the alternation of dactyls and spondees mirror the women's spasmodic gasping for breath as they sob.

12 I am grateful for the following information which was brought to my attention. There is a clash of metrical beat and word stress in the latter half of 4. 664: énsèmque. See Claassen, art. cit., 83, who detects a sign of emotional strain in the verse, and her reference to W.R. Nethercut, "Daphne and Apollo: a dynamic encounter", CJ 54 (1979) 333-347. Of course word stress and metrical beat conflict in Aen. 4, 3. See the scansion on this page.

13 I agree with Claassen, ant. cit., 82, who remarks that this is one of the verses which appear to convey the strongest emotion. 
Then Anna hears the news:

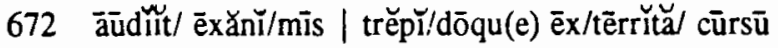

673 ūngŭbŭs/ ōră sŏ/rör | fōē/dāns ēt/ pēctŏră/ pūgnīs

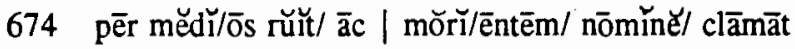

In these three successive verses there are eight diaereses, each time at the end of the fifth foot, which is most unusual; they help to create the uneven effect. The preponderance of dactyls four each in 672 and 674 - mimics the suddenness with which Anna hears the news and her frantic attempt to reach Dido. The irregular pattern of heavy and light syllables in 675-677:

hōc îl/lūd gēr/mānă | fŭ/ît? mē/ frāūdĕ pĕ/tēbās

hōc rŏgŭs/ ìstě mŭh(i),/ hōc | īg/nēs à/rāēquĕ pă/rābānt?

quīd $\mathrm{prī} / \mathrm{mūm}$ dē/sērtă | quĕ/rär? cŏmĭt/ēmnĕ sŏ/rōrēm

and the awkward elision of mih(i) hoc creates the impression of uncontrollable agitation in Anna's thoughts.

\section{CONCLUSION}

In order to retain scansion as a useful exercise in schools, I would suggest that (1) quantity should be taught from the first year with paradigms and new words, but unobtrusively, merely by the teacher's correct pronunciation; (2) in the reading of prose, the word accentuation should be given correctly, again by example, without adding to the pupil's load; (3) if at all possible the pronunciation of vowels should be standardised; (4) poetry should be read aloud as such by the teacher. If the ground is prepared, the pupil need experience no difficulty when he meets scansion. $14 \mathrm{He}$ should be encouraged to use his new skill as a source of pleasure and an aid to the appreciation of poetic craftsmanship.

\section{BIBLIOGRAPHY}

Allen, W.S. 1965, Vox Latina. Cambridge: Cambridge University Press.

Allen, W.S. 1973. Accent and rhythm: prosodic features of Greek and Latin. Cambridge: Cambridge University Press.

Herbert, A.P. 1966. "The Dead Pronunciation", in: Wigs at work. Harmondsworth: Penguin.

Kenney, E.J. \& Clausen, W.V. (eds) 1982. The Cambridge history of classical literature, vol. II. Cambridge: Cambridge University Press.

Raven, D.S. 1965. Latin metre, an introduction. London: Faber and Faber.

Scholtemeijer, J. \& Hasse, P. 1989. Legal Latin: a basic course. Pretoria: Academica Press.

14 I think back on my own struggle to learn the Greek accents in my third year, and often wonder whether it would have been less of an effort if the rules had been taught with each new word and paradigm. 